\title{
Cultural Dialogue and Human Solidarity: The Rorty - Habermas-Debate Revisited in the Light of Wittgenstein's Philosophy
}

\author{
BORIS GUBMAN, TVER
}

The R. Rorty - J. Habermas debate on the issues of cultural dialogue and the horizons of human solidarity is largely based on the problems raised in of L. Wittgenstein's philosophy. Despite their discord in interpreting the subject, both thinkers appeal to Wittgenstein's understanding of language, communication, and culture thus revealing possible strategies of approaching this issue related to his theoretical heritage. Although Rorty and Habermas differ in evaluation of Wittgenstein's thought, they are in complete agreement concerning the radical changes in contemporary philosophical stance of philosophizing that made his theoretical heritage highly significant. Declaring their opposition to the traditional metaphysics, Rorty and Habermas show philosophical and political divergences that become evident in their treatment of the issue of cultural dialogue and human solidarity.

Wittgenstein's criticism of the classical metaphysical tradition paved the way for the contemporary attempts to generate a new pattern of philosophical reflection. His irony was aimed first and foremost at destroying all forms of metaphysical constructions pretending to provide a global and all-embracing picture of reality (Wittgenstein 1980, 16e). Any finite foundation of our chain of arguments is questionable, but the infinite field of our thought confined within limits of language always surpasses our understanding (Wittgenstein 1980, 16e). This kind of 'theoretical mysticism' is the origin of his irony revealing the futility of all uncritical metaphysical constructions. It evidently gives nourishment to the anti-metaphysical declarations of his followers.

Opposition to the classical stance of philosophizing means for both Rorty and Habermas the rejection of Platonic-Aristotelian ontological constructions of reality, as well as the Cartesian-Kantian philosophy of con- 
sciousness. Their interpretations of Wittgenstein's role in the change of the philosophical paradigm from metaphysical to post-metaphysical are motivated by non-coinciding visions of this radical change. Given the existing polarity of their views, Rorty believes that this kind of disagreement is more philosophical than political due to the fact that he and Habermas share the same liberal values. However, their philosophical differences lead to a serious divergence in interpreting the task of contemporary liberalism.

Critisizing the metaphysical tradition of the past, Rorty launched a strong attack on the foundations of the Platonic-Aristotelian view of the universe, its essential foundations (Rorty 1979, 43f). At the same time, he hopes 'to break with the picture which, in Wittgenstein's words, 'holds us captive'- the Cartesian-Lockean picture of a mind seeking to get in touch with the reality outside itself" (Rorty 1999, XVII). Among the European post-Nietzschean philosophers, who helped to destroy the fortress of metaphysics, he mentions not only Wittgenstein's name, but also M. Heidegger, J.-P. Sartre, H.-G. Gadamer, and J. Derrida, while the most famous American post-Darwinian thinkers in this process are W. James, J. Dewey, Th. Kuhn, W. Quine, H. Putnam, and D. Davidson. (Rorty 1999, XIX).

Rorty's farewell to the classical metaphysics is apparently based on the idea that language is the only reality we are capable of knowing in its uniqueness and contingency: "To drop the idea of languages as representations, and to be thoroughly Wittgensteinian in our approach to language, would be to de-divinize the world" (Rorty 1989, 21). However, trying to be true to the spirit of Wittgenstein's language philosophy, Rorty comes to conclusions that sound like obvious deviations from his thought. Wittgenstein spoke of the representation problem as related to a variety of existing language games translating our experience in terms of their rules - "our method of representation" (Wittgenstein 1964, 25). Simultaneously, irrespective of his theory of family resemblances and in accord with it, he opposed extreme nominalism: "Nominalists make the mistake of interpreting all words as names, and so of not really describing their use, but only, so to speak, giving a paper draft on such a description" (Wittgenstein 1964, 118). Within the format of language-game theory, the rules prevailing in their context are playing a quite important role thus revealing certain general aspects within the concrete communicational milieu. 
Nominalism and historicism, Rorty believes, should be viewed as a direct result of his liberal ironist pattern of philosophical reflection that is deeply rooted in the tradition of Romanticism and contradicting the rationalism of the Enlightenment. This kind of ironism is inconceivable without the contemporary understanding of language contingency in the key of Wittgenstein and Davidson. "Ironists who are inclined to philosophize see the choice between vocabularies as made neither within a neutral and universal meta-vocabulary nor by an attempt to fight one's way past appearances to the real, but simply by playing the new off against the old" (Rorty 1989, 73). Nevertheless, despite the conventional basis of the comparison between vocabularies, the history of producing different branches of human knowledge is nothing other than the process of such a competition. Meta-language production is a legitimate part of any kind of knowledge although one is never able to introduce a perfect meta-discourse clarifying scientific or non-scientific problems.

In the key of liberal ironist pattern of reflection, the claim of the incomparability of different vocabularies is a step forward to denying the idea of rationality as belonging to the classical stance of philosophical thought and incompatible with nominalism and historicism (Rorty 1989, 74f). Rorty's hostility to the idea of rationality could not be justified on the basis of Wittgenstein's language philosophy. If we follow Wittgenstein's train of thought, rules may be interpreted as certain rational patterns that govern human language practices (Wittgenstein 1964, 27). Wittgenstein introduced also the idea of certain continuity in language games, claiming that less complex language games could help more general ones to emerge. "We see that we can build up the complicated forms from the primitive ones by gradually adding new forms" (Wittgenstein 1960, 17). If so, one should reflexively uncover rules governing language games in their continuity revealing the inner rational patterns that persistently survive and change in time. "Philosophy is a battle against the bewitchment of our intelligence by means of language" (Wittgenstein 1960, 47). Its task, in the key of Wittgenstein's interpretation, is a rational activity clarifying rules of language games as well as life forms that exist in human culture.

Davidson, whose theoretical thought was a source of inspiration of Rorty's understanding of language, spoke of the inner rationality existing in its milieu. "Seeing rationality in others is a matter of recognizing our 
own norms of rationality in their speech and behavior. These norms include the norms of logical consistency, of action in reasonable accord with essential or basic interests, and the acceptance of views that are sensible in the light of evidence" (Davidson 2005, 319). Thus, representing and interpreting human actions, Davidson believes, we are attributing to them a kind of rationality (Davidson 2004, 169). Otherwise, understanding of the other peoples, who exist in different language milieus, becomes totally impossible (Davidson 2005, 315-327).

In his severe criticism of metaphysical philosophizing, Habermas is very close to Rorty's line of arguments. The first version of metaphysical interpretation of reality was formed, in his view, in the manner of PlatonicAristotelian search for its ultimate substantial ground and was prevailing throughout the antiquity and the Middle Ages despite the existing opposition of different forms of materialism and nominalism. This holistic view of the world was deeply related to the desire to find the ideal patterns of the existing realities in the way Plato did. With the arrival of Modernity, the philosophy of consciousness from Descartes to Kant took the major role in the further development of the metaphysical tradition (Habermas 1994, 31). The strong understanding of theory accompanied the metaphysical world view that was destroyed in the course of successful attacks launched by the representatives of different currents of contemporary philosophical thought.

Wittgenstein's "therapeutic" criticism of metaphysics together with the efforts of the representatives of structuralism, post-structuralism, neoMarxism and neo-pragmatism contributed greatly to the devaluation of metaphysics and the growing persuasion of a need to find a new strategy defining philosophy's future (Habermas 1994, 37f). However, despite the acknowledged value of Wittgenstein's thought for discrediting metaphysics, Habermas is not at all willing to accept his program. "Wittgenstein championed the notion of a therapeutic philosophy, therapeutic in the specific sense of self-healing, for philosophy was sick to the core... The weakness of this particular farewell to philosophy is that it leaves the world as it is" (Habermas 1995, 11). No less skeptical is his attitude to Rorty's interpretation of Wittgenstein that is evaluated as being detrimental for the understanding philosophy's role in contemporary philosophical situation (Habermas 1995, 11). Unlike Rorty, Habermas is not at all willing to break 
with the Enlightenment's pattern of philosophical reflection and its rationalist and universalist foundations.

Despite the crisis of the classical metaphysics, Habermas is convinced that philosophy should find new horizons for its development in a radically changing world. Its mission today consists of being a witness and a mediator. As a rational effort to reconcile various branches of diversified human knowledge and to build a bridge of confidence and understanding between alienated areas of culture, philosophy should be free to develop on a communicative basis. Rationality and universality may triumph not only in the sphere of knowledge, but also in the realm of norms governing the relations of society where I. Kant's categorical imperative should be persistently present as a guiding principle of norm justification and selection (Habermas 1995, 58).

Responding to Rorty's criticism, Habermas claims that universality and rationality in the activity of theoretical and practical reason are quite independent of the context of particular lifeworlds. At the same time, only a particular lifeworld is able to translate the universal insights into concrete moral action (Habermas 1995, 109). If so, one can discover a possible reconciliation point between Habermas and Wittgenstein despite their differing views. Life forms existing within the variety of language games may produce certain rules of accepted human behavior that can either nourish and support a particular kind of moral persuasions and norms of law based on a certain agreement or facilitate their refutation.

Rorty believes that his disagreement with Habermas is purely philosophical leading to no basic political disaccord (Rorty 1989, 67). At the same time, it is obvious that both Habermas and Rorty are preparing the ground for their political thought by the chain of philosophical arguments. Rorty's liberal ironist approach to politics based on his nominalism and historicism produces the effect of a radical divorce between the private and the public spheres. On the contrary, Habermas bridges the gap between the spheres of private, public, and political life through communication revealing certain universal norms of human conduct that should be established through transcendental-pragmatic justification (Habermas 1996, 368f). Thus, communicative philosophical approach and a republican-liberal pattern of political thought appear to be mutually complementary. 
Habermas believes that Kant's categorical imperative should constitute a basis for morality and politics of a democratic society. But this universalist perspective needs some kind of permanent translation process given a vast variety of lifeworlds and is therefore unacceptable for someone like Rorty. Dealing with this problem, Habermas comes closer to Wittgenstein and is willing to accept the value of his thought. At the same time, despite the adopted nominalist and historicist perspective of thought, a liberal ironist still needs the common ground of human solidarity for constructing a picture of inter-human social relations. A feeling of solidarity is born out of our sensibility to the other human being's pain and humiliation and is a specific fruit of consciousness of the "inhabitants of the democratic states" (Rorty 1989, 198). Solidarity thus understood has to be constructed "out of little pieces" rather than found as a universal "ur-language". In this perspective, even if solidarity is a fruit of a community of liberal democratic societies, it is conceivable as something leading to a general notion of human dignity that is coined in the process of communication. To put a certain boundary on the way of its expansion would be totally undemocratic and contradicting the spirit of an open language game.

Like in the area of theoretical philosophy, dealing with social and political issues, Rorty interpreted Wittgenstein's language game theory in the key of extreme nominalism and historicism. Rightly emphasizing the uniqueness of different cultural worlds, he came to a paradox of human solidarity that demands the coinage of a general notion of solidarity applicable in communicative praxis in different lifeworlds. Thus, political philosophy most clearly reveals the limits of his understanding of Wittgenstein's thoughts. In the same political philosophy area, one can also locate a certain deficit of Habermasean thought. Habermas acknowledges Wittgenstein's role in the criticism of classical metaphysics, but underestimates his philosophical strategy as merely a "therapeutic" one. Defending rationalism and universalism on the basis of his theory of communication within the format of his debate with Rorty, Habermas comes to the problem of translating of general moral and legal norms into the practice of human action. His interpretation of norm formation and their translatability in the lifeworld context looks like an invitation to a more complete analysis of this problem that might be possible in the perspective of Wittgenstein's language philosophy. 


\section{Summary}

The R. Rorty-J. Habermas debate on the issues of cultural dialogue and horizons of human solidarity is largely based on the problems raised in L. Wittgenstein's philosophy. Rorty's radical postmodernist stance of neopragmatist philosophizing is totally opposite to the strategy developed within the neo-Marxism of Habermas. Following D. Davidson, Rorty believes that the uniqueness of each culture means its non-translatability into the language of the alien cultural context. Habermas, on the contrary, is persuaded that language constitutes the milieu of universally expanding communication bringing about the opportunity of an ideal pattern of human understanding. Deeply rooted in the reflexive pattern of the Enlightenment, his theory of communicative action culminates in the claim that I. Kant's categorical imperative is still of vital importance providing the universal foundation of human relations irrespective of cultural and social diversity. As a liberal ironist, Rorty declares his indebtedness to the Romantic pattern of cultural reflection. However, his emphasis on the uniqueness of cultural phenomena appears to be reconcilable with the quite universalistic view permitting to accept the values of fellow-humans on the basis of compassion and the need for human solidarity in a combat against cruelty and violence.

\section{REFERENCES}

Davidson, D. 2004 Problems of Rationality, Oxford: Clarendon Press.

Davidson, D. 2005 Truth, Language, and History, Oxford: Clarendon Press.

Habermas, J. 1995 Moral Consciousness and Communicative Action, Cambridge MA: MIT Press.

Habermas, J. 1994 Postmetaphysical Thinking, Cambridge MA: MIT Press. Habermas, J. 1996 Between Facts and Norms, Cambridge: Polity Press.

Rorty, R. 1989 Contingency, Irony, and Solidarity, Cambridge: Cambridge University Press.

Rorty, R. 1979 Philosophy and the Mirror of Nature, Princeton, New Jersey: Princeton University Press. 
Rorty, R. 1999 Philosophy and Social Hope, London; New York: Penguin.

Wittgenstein, L. 1980. Culture and Value, G.H. Wright (ed.), Chicago: University of Chicago.

Wittgenstein, L. 1964 Philosophical Investigations, New York: The MacMillan Company.

Wittgenstein, L. 1960 Preliminary Studies for the "Philosophical Investigations" generally known as "The Blue and Brown Books", Oxford: Basil Blackwell. 